\title{
Contribution Factors in Affecting Teacher Performance: Principal Managerial Skills and Work Motivation
}

\author{
Roemintoyo $^{1 *}$, Hasan Tauhid ${ }^{2}$, Noormiyono ${ }^{3}$, Mochamad Kamil Budiarto ${ }^{4}$ (D) \\ ${ }^{1,4}$ Faculty of Teacher Training and Education, Sebelas MaretUniversity, Surakarta, Indonesia \\ ${ }_{2}^{2}$ Primary School Teacher, Demak, Indonesia \\ ${ }^{3}$ PGRI University Semarang, Semarang, Indonesia
}

\section{A R T I C L E I N F O}

Article history:

Received March 19, 2021

Revised April 05, 2021

Accepted May 03, 202

Available online May 25, 2021

\section{Kata Kunci:}

Keterampilan Manajerial,

Kepalasekolah, Kinerja,

Motivasi

\section{Keywords:}

Managerial Skills, Motivation,

Teacher, Performance,

Headmaster

\begin{abstract}
A B S T R A K
Rendahnya kinerja guru menjadi permasalahan yang saat ini dihadapi oleh lembaga pendidikan. Ditengah tuntutan penguasaan kompetensi yang semakin kompleks, peran guru sebaga fasilitator pembelajaran menjadi penting dalam memfasilitasi peserta didik untuk mencapai kompetensi - kompetensi yang dibutuhkan di era global seperti saat ini. Melalui penelitian yang bertujuan untuk mengetahi pengaruh faktor yang berkontribusi terhadap kinerja guru, yaitu keterampilan manajerial kepala sekolah dan motivasi kerja diharapkan mampu menjadi landasan dalam membuat inovasi kebijakan yang mampu meningkatkan produktivitas dan kinerja guru. Penelitian ini merupakan penelitian kuantitatif. Sampel penelitian terdiri dari 128 guru. Angket menjadi instrument pengumpulan data yang digunakan pada kegiatan penelitian. Data yang terkumpul kemudian dianalsisi menggunakan rumus regresi sesuai dengan variabel yang akan diuji. Hasil penelitian ini menunjukkan bahwa, terdapat pengaruh keterampilan manajerial kepala sekolah terhadap kinerja guru sebesar 77,1\%, faktor lainnya adalah motivasi, pengaruh motivasi kerja terhadap kinerja guru sebesar $74,6 \%$, dan untuk kedua variabel keterampilan manajerial kepala sekolah dan motivasi kerja secara bersama-sama berpengaruh terhadap kinerja guru sebesar 87,7 \%. Dari hasil temuan pada penelitian ini dapat disimpulkan bahwa fluktuasi naik turunnya kinerja guru sangat dipengaruhi oleh dinamika manajerial kepala sekolah dan motivasi kerja guru. Selain beberapa faktor lain yang juga turut memberikan kontribusi dalam peningkatan kinerja guru.
\end{abstract}

\section{A B S T R A C T}

The low performance of teachers is a problem currently faced by educational institutions. In increasingly complex demands for mastery of competencies, the role of teachers as learning facilitators is essential in facilitating students to achieve the competencies needed in the global era like today. Through research that aims to determine the influence of factors that contribute to teacher performance, namely the managerial skills of principals and work motivation, it is hoped that they will become the basis for making policy innovations that can increase teacher productivity and performance. This research is quantitative. The research sample consisted of 128 teachers. The questionnaire is the data collection instrument used in research activities. The collected data is then analyzed using a regression formula by the variables to be tested. This study indicates that there is an effect of principal managerial skills on teacher performance by $77.1 \%$, other factors are motivation, the effect of work motivation on teacher performance is $74.6 \%$, and for the two variables, principal managerial skills and work motivation are variable. Jointly affect teacher performance by $87.7 \%$. From the findings in this study, it can be concluded that fluctuations in teacher performance fluctuations are strongly influenced by the organizational dynamics of school principals and teacher work motivation, apart from several other factors that also contribute to improving teacher performance.

This is an open access article under the CC BY-SA license.

Copyright (c) 2021 by Author. Published by Universitas Pendidikan Ganesha

\section{INTRODUCTION}

Teacher performance is the ability of a teacher to carry out activities by predetermined goals, including aspects of planning teaching and learning programs, implementing the teaching and learning process, creating and maintaining optimal classes, controlling optimal learning conditions, and assessing learning outcomes. The quality of teachers, which is reflected in their performance, is one of the determining factors for the quality of education (Ahmadiansah, 2018; Sari, 2019). Many things strongly influence the strategic position of teachers to improve the quality of educational outcomes, including personal characteristics, managerial and leadership styles, supervision, work discipline, teacher motivation, and school environment (Putri \& Imaniyati, 2017; Pratiwi et al., 2021). As the highest leader in educational institutions at the school level, the principal has 
characteristics and leadership patterns that can determine school performance (Aryantini, Agung, \& Dantes, 2018; Lisnawati, 2018; Yusuf, 2012).

Skill can carry out tasks based on job competence, and the results can be observed (Suardana, Yudana, \& Agung, 2018; Wahyudi, 2012). Managerial skills are stated as profound abilities regarding leadership matters. A reliable school principal requires several specific skills in running his organization (Putri \& Imaniyati, 2017; Usman \& Husaini, 2015). Through these specific skills will be able to help leaders of educational institutions achieve the goals of the institution concerned effectively and efficiently. One of the skills contributing to improving school performance and owned by the principal is managerial skills (Putri \& Imaniyati, 2017; Amri et al., 2021). This ability can motivate people in the environment where he works so that it will provide impact on the performance of the people around them, especially educators and education personnel. The managerial skills of school principals were one of the factors that dominate the achievement and success in carrying out tasks. Besides that, the managerial abilities possessed by school principals are proven to have a significant effect on teacher performance (Widodo, 2017; Yayuk \& Sugiyono, 2019). Three kinds of managerial skills needed by a principal as an educational leader in managing school organizational resources, namely technical skills, human relations skills, and conceptual skills (Widodo, 2017). These three skills are essential for effective management (Sudirman et al., 2021; Widodo, 2017). This is indicated by the ability and expertise in planning, controlling and performing supervisory functions. Principals who have the excellent managerial ability will provide a favourable working climate to achieve predetermined goals and targets.

The results of previous research regarding the Relationship of Principal Managerial Skills, School Climate, and Teacher Work Spirit to Teacher Performance at Public Senior High Schools in Merauke City concluded that there was a positive and significant relationship between principal's managerial skills and teacher performance (Werang, 2011). Another study also revealed that the results showed the magnitude of the influence of the principal's transformational leadership on school quality (Maris et al., 2016). The reality in the field showed that different teacher motivations often cause problems. Teachers who have work experience sometimes do not show an attitude that deserves an example (Sumantri \& Whardani, 2017). Primary school principals, most of whom do not have staff, are often an obstacle to the performance of the school principal, both in making school work programs and supervising learning, which will affect improving school quality. As a preliminary study conducted through interviews with 30 teachers in one of the public elementary school clusters in Bonang District,: (a) there are 30\% of teachers who have not prepared learning tools (b) $40 \%$ of teachers are preparing learning tools when supervisors will be held (c) $50 \%$ of teachers used learning tools in the previous year (d) $75 \%$ of teachers did not analyze the test results. Furthermore, the quality of SD level graduates in the Bonang Demak sub-district is shown in the following Table 1.

Table 1. Results of the National Examination of Elementary School in Academic Year of 2012-2014

\begin{tabular}{|c|c|c|c|c|c|c|c|c|c|c|}
\hline \multirow{3}{*}{ No } & \multirow{3}{*}{ Academic year } & \multicolumn{9}{|c|}{ Subjects } \\
\hline & & \multicolumn{3}{|c|}{ Indonesian } & \multicolumn{3}{|c|}{ Mathematics } & \multicolumn{3}{|c|}{ Science } \\
\hline & & $\mathbf{R}$ & $\mathbf{T}$ & $\mathbf{R t}$ & $\mathbf{R}$ & $\mathbf{T}$ & $\mathbf{R t}$ & $\mathbf{R}$ & $\mathbf{T}$ & $\mathbf{R t}$ \\
\hline 1 & $2011 / 2012$ & 6,09 & 8,20 & 7,15 & 4,64 & 8,89 & 7,12 & 6,01 & 8,39 & 7,15 \\
\hline 2 & $2012 / 2013$ & 6,48 & 8,95 & 7,82 & 4,94 & 9,04 & 7,29 & 5,49 & 8,16 & 6,72 \\
\hline 3 & $2013 / 2014$ & 2,40 & 9,80 & 7,52 & 2,75 & 8,75 & 6,80 & 3.00 & 9,50 & 6,74 \\
\hline
\end{tabular}

As illustrated in the above phenomenon, the low teacher performance is thought to have something to do with the managerial skills of school principals. The managerial skills of school principals as written in Permendiknas Number 13 of 2007 concerning Principal Standards include: (1) Preparing school plans for various planning levels (2) Developing school organizations according to needs, and (3) Utilizing school resources. In addition to the managerial skills of school principals, several other factors influence school quality, including organizational culture, organizational climate, facilities and infrastructure, teacher performance and individual motivation (Maris et al., 2016; Purwoko, 2018). One of the several factors mentioned above is the motivation inherent in each individual is work motivation, and this motivation dramatically affects a teacher's performance (Ariyanti, 2020; Ulum et al., 2020). Work motivation is work motivation, both from within and outside humans, to carry out an activity. Work motivation plays a vital role in providing passion, enthusiasm and pleasure at work so that those who have high motivation will also have much energy to carry out activities (Ningrat, Agung, \& Yudana, 2020; Sudiarditha, Waspodo, \& Triani, 2017; Sumantri \& Whardani, 2017). Teachers who have high motivation are very few who are left behind on assignments, and there are also very few mistakes in their work (Hartanti \& Yuniarsih, 2018). Motivation is defined as the strength that arises from within the individual to achieve specific goals and benefits in the world of work (Danim, 2012; Sari, 2019). It can be said that high or low teacher performance is also influenced by teacher work motivation. Work motivation arises because there are various needs that educators want to meet (Lisnawati, 2018; Dhiu, 2017). Motive as a process 
within the individual encourages action so that the motive is an internal organic process. This is in line with several studies that show that motivation is a factor that contributes to improving teacher achievement and performance in carrying out their duties and responsibilities as an educator.

The description above shows that through the possession of professionalism in terms of education management, the principal is expected to formulate an effective school program, able to create a conducive institutional environment and organizational culture in schools. The principal constantly interacts with his subordinate teachers, supervises and assesses the activities carried out both administratively and non administratively. As previously mentioned, teachers' low performance will impact the effect of completing assignments and hampering the achievement of educational goals. Low teacher performance can be overcome by identifying the factors that influence it, as some of the opinions above state that various factors contribute to teacher performance (Ahmadiansah, 2018; Satriyono \& Vitasmoro, 2018; Yusuf, 2012). This study explores the relationship between the principal managerial ability factor and work motivation on teacher performance. So that through this research it can increase the identification of the factors so far affecting teacher performance in carrying out their duties and obligations.Low teacher performance can be overcome through identification of the factors that influence it, as some of the opinions above state that there are various factors that contribute to teacher performance (Almutairi \& Shraid, 2021). This study tries to explore the relationship between the principal managerial ability factor and work motivation on teacher performance. So that through this research it can increase the identification of the factors so far affecting teacher performance in carrying out their duties and obligations. Therefore, school principals need various managerial competencies to be able to improve the quality and quality of educational institutions. Given that competence is one of the many factors that contribute to improving the quality of education. This study aims to determine (a) the magnitude of the influence between the principal's managerial skills and work motivation on teacher performance (b) the magnitude of the influence of the two variables simultaneously on teacher performance.

\section{METHOD}

This research uses a quantitative approach, with the aim of knowing the relationship between the independent and dependent variables, this study was conducted in the 2014/2015 school year. The following is an illustration in the form of an image regarding the research design to determine the relationship between variables.

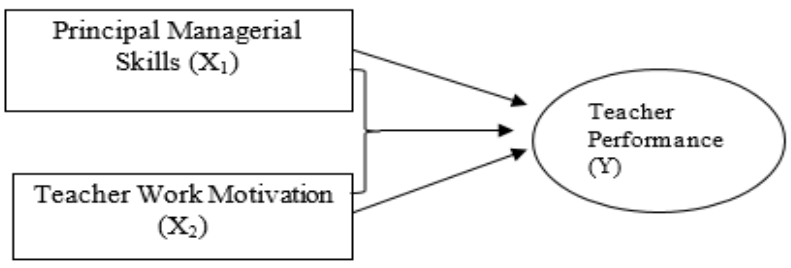

Figure 1. Research Design

In this study, the population in this study were all State Elementary School teachers in Bonang District, Demak Regency, in general, 189 teachers from 36 schools divided into 6 "Dabin". Meanwhile, the research sample consisted of 128 teachers selected using the Slovin formula, which was determined using a proportional random sampling technique for each "Dabin". The data collection method is using a questionnaire. The instrument used in this study was a questionnaire consisting of a teacher work motivation questionnaire and a principal managerial skills questionnaire. Before distributing each questionnaire, it must first go through a test, and this test aims to determine the validity and reliability of the instrument.

An instrument validity test was carried out by taking a sample of 30 teachers. The validity test technique uses the Product Moment formula (Arikunto, 2010). The analysis results using the Product moment formula with a threshold of 0.361 obtained the principal managerial skills variable with 19 indicators, 3 (three) indicators that are invalid. There are 19 teacher work motivation variables, 2 (two) invalid indicators and 19 teacher performance variable indicators, and 5 (five) invalid indicators. The next test is the reliability test of the data collection instrument and the validity test, and this test is carried out with a sample of 30 teachers. The response data from the sample were then entered into the SPSS for Windows program to determine the level of reliability. The questionnaire instrument is declared reliable if it has a Cronbach alpha value $>0,7$. The results showed that each data collection instrument was included in the reliable category, with details, namely that the Principal Managerial Skills obtained a calculation of 0.888 , which means that it is more significant than 0.7 so that the instrument is declared valid. Furthermore, the Teacher Motivation questionnaire obtained a calculation of $0.934>0.7$, which was included in the reliable category. The Teacher Performance questionnaire obtained a 
score of 0.873 which means greater than $0.7(>0.7)$ so that it is included in the category of reliable instruments as a data collection tool. More details related to reliability test results can be seen in the following Table 2 .

Table 2. Reliability Test Results

\begin{tabular}{clcc}
\hline No & \multicolumn{1}{c}{ Variabel } & Results & information \\
\hline 1 & Principal Managerial Skills & 0.888 & Reliable \\
2 & Teacher Motivation & 0.934 & Reliable \\
3 & Teacher Performance & 0.873 & Reliable \\
\hline
\end{tabular}

The data analysis technique used in this study is regression analysis by the causal relationship to be tested. This regression analysis was conducted to test 1) the relationship between principal managerial skills (X1) and teacher performance (Y), 2) the relationship between work motivation (X2) and teacher performance $(\mathrm{Y})$, then multiple regression analysis to examine the relationship between principal managerial skills. (X1) and work motivation (X2) on teacher performance (Y).

\section{RESULT AND DISCUSSION}

Based on the Table 3, it can be seen that the correlation coefficient value between managerial skills of principals and teacher performance is 0.878 . This means that it can be concluded that the two variables have a strong relationship which is indicated by a correlation value close to 1 . To find out the magnitude of the influence of the principal's managerial skills $(\mathrm{X} 1)$ on teacher performance (Y), namely the coefficient of determination (R2). The value of the coefficient of determination (R2) of 0.771 . These results indicate that the influence of managerial skills of school principals $(\mathrm{X} 1)$ on teacher performance $(\mathrm{Y})$ is $77.1 \%$ and other variables outside the principal managerial skills that affect teacher performance are equal to $22.9 \%$. The correlation coefficient value between work motivation and teacher performance is 0.863 . This means that it can be concluded that the two variables have a strong relationship which is indicated by a correlation value close to 1 . To find out the magnitude of the influence of work motivation (X2) on teacher performance (Y), namely from the value of the coefficient of determination (R2), by looking at the R Square value in the Output Table. The coefficient of determination (R2) of 0.746 means that the effect of teacher work motivation (X2) on teacher performance $(\mathrm{Y})$ is $74.6 \%$ and other variables outside of work motivation that affects teacher performance are 25.4. \%. The results of the correlation test between the variable principal managerial skills and motivation on teacher performance are as Table 4.

Table 3. The results of the correlation test of variable $\mathrm{X}_{1}$ to variable $\mathrm{Y}$

\begin{tabular}{llrr}
\hline & Performance & Managerial \\
\hline \multirow{2}{*}{ Performance } & Pearson Correlation & 1 & $0.878^{* *}$ \\
& Sig. (2-tailed) & & 0.000 \\
& N & 128 & 128 \\
& Pearson Correlation & $0.878^{* * *}$ & 1 \\
Managerial & Sig. (2-tailed) & 0.000 & 128 \\
& N & 128 & 128 \\
\hline
\end{tabular}

**. Correlation is significant at the 0.01 level (2-tailed)

Table 4. The results of the correlation test of variables $X_{1}$ and $X_{2}$ to variable $Y$

\begin{tabular}{llrrr}
\hline & \multicolumn{2}{c}{ Performance } & Managerial & Motivation \\
\hline \multirow{3}{*}{ Performance } & Pearson Correlation & 1 & $0.878^{* *}$ & $0.863^{* *}$ \\
& Sig. (2-tailed) & & 0.000 & 0.000 \\
& $\mathrm{~N}$ & 128 & 128 & 128 \\
& Pearson Correlation & $0.878^{* *}$ & 1 & $0.727^{* *}$ \\
Managerial & Sig. (2-tailed) & 0.000 & & 0.000 \\
& $\mathrm{~N}$ & 128 & 128 & 128 \\
& Pearson Correlation & $0.863^{* *}$ & $0.727^{* *}$ & 1 \\
Motivation & Sig. (2-tailed) & 0.000 & 0.000 & 128 \\
& $\mathrm{~N}$ & 128 & 128 & \\
\hline
\end{tabular}

**. Correlation is significant at the 0.01 level (2-tailed) 
Based on the Table 4, it can be explained that the correlation between the managerial skills of school principals and teacher performance is 0.878 . The correlation between work motivation and teacher performance is 0.863 . A positive coefficient value indicates a positive relationship. If the principal managerial skills and teacher motivation increase, the teacher's performance will also increase. The results of the regression test to determine the magnitude of the influence of principal managerial skills (X1) and teacher work motivation (X2) simultaneously on teacher performance (Y) by looking at the R Square value in the Summary Model Output. The test results obtained an adjusted R2 value of 0.877 , which means that the variable effect of principal managerial skills (X1) and work motivation (X2) together on teacher performance (Y) is $87.7 \%$, and the rest is $12.3 \%$ teacher performance-influenced by other variables. Furthermore, to find out the multiple regression equation from the research variables.

Based on the regression test of the first hypothesis, it can be seen that the principal's managerial skills have a strong relationship with teacher performance, which is indicated by a correlation value of 0.878 , and the magnitude of the effect of managerial skills on teacher performance is 0.771 or $77.1 \%$. Based on these findings, it can be explained that the principal's managerial skills have a strong influence on teacher performance. The rise and fall of teacher performance will depend on how managerial the teachers perceive the principal. The better the managerial ability of the principal where the teacher works, the better, and the teacher's performance will increase. This result is in line with other research which states that there is a positive influence that occurs between the principal's leadership on the performance of teachers in carrying out their duties and obligations, although there are other factors that contribute to the results of teacher performance, the principal's leadership has a significant contribution (Purwoko, 2018; Ramadoni, Kusmintardjo, \& Arifin, 2016). Principals of elementary schools in Bonang Demak Regency must also pay attention to other factors $(22.9 \%)$ that affect performance. If this is not encouraged by the principal, it can also trigger a decline in teacher performance. Other factors can come from internal and external schools, for example, teacher competence, organizational climate, work culture (Djafar \& Nurhafizah, 2018; Lumban Gaol \& Siburian, 2018; Yani, 2015). The leadership level of the principal has a significant relationship. It is proven that there is a significant relationship between individual abilities and teacher performance in carrying out tasks (Subagia, Yudana, \& Divayana, 2019; Yusuf, 2012).

Regarding the regression test on the second hypothesis, namely the relationship between work motivation $\left(\mathrm{X}_{2}\right)$ and teacher performance $(\mathrm{Y})$. It can be seen that teacher work motivation has a strong correlation to teacher performance as indicated by the correlation value of 0.863 and the magnitude of the influence of teacher work motivation on teacher performance is 0.746 or $74.6 \%$. Through these findings, it can be identified that teacher work motivation has a strong influence on teacher performance. Therefore, if the principal is better at approaching to motivate teachers, the better and the teacher's performance will increase, and vice versa. Motivation is a condition or energy that moves employees who are directed or aimed at achieving the goals of the school organization (Mangkunegara, 2014; Usman \& Husaini, 2015). Motivation functions as a motor for humans, like fuel in a vehicle (Fanselow, 2018). Therefore, teacher motivation in teaching must be maintained to carry out the teacher's desire in delivering the subject matter (Lisnawati, 2018; Hartanti \& Yuniarsih, 2018). The results of multiple regression tests on the two independent variables showed that the correlation value $\mathrm{X}_{1}$ to $\mathrm{Y}$ was 0.878 and the correlations value $\mathrm{X}_{2}$ to $\mathrm{Y}$ was 0.863 . The effect of principal managerial skills and teacher work motivation together on teacher performance is 0.877 or $87.7 \%$ with the regression equation $\hat{\mathrm{Y}}=1.521+0.473 \mathrm{X} 1+0.399 \mathrm{X}_{2}$, indicating that the two independent variables (principal managerial skills and work motivation) has a positive and significant effect.

This result is in line with several studies that have been conducted regarding the factors that contribute to teacher performance. the perspective of the leader of an educational institution or institution will affect the cultural climate and performance in the educational institution, so that the leader of an educational institution must master both theoretically and practically several competencies in managing and competencies regarding educational theories, so that it is likely that the leader will be able to bring teachers and staff to be more productive (Dery, 2021; Yayuk \& Sugiyono, 2019). In addition, what is considered important and contributes to improving performance is the perfectionist nature and stress management of the leadership of the institution, it is imperative that a leader be able to regulate the nature of stress in facing problems, so that he does not rush in making policies (Lumban Gaol \& Siburian, 2018). On the other hand, factors such as motivation, managerial ability, teacher competence, the ability of both teachers and principals to innovate, commitment in carrying out tasks have a contribution to improving teacher performance (Lumban Gaol \& Siburian, 2018; Purwoko, 2018; Ariyani, 2021; Lumban Gaol \& Siburian, 2018; Almutairi \& Shraid, 2021).

The results of these findings can also explain that the better the managerial skills of school principals are supported by high teacher work motivation, the two variables will significantly improve the performance of elementary school teachers in Bonang, Demak District, on the other hand, if the two independent variables are not suitable, then teacher performance will also decline. The leadership effectiveness of the principal will be evident if the principal can create a conducive school atmosphere and provide work motivation (Alfathan \& Saleh, 2018; Lisnawati, 2018; Werang, 2011). Therefore, it will improve the performance of educators in order 
to achieve goals, visions, and the institution's mission. Leaders in educational institutions need to have management skills. It is proven by the results of this study which indicate that the factor that also contributes to improving teacher performance is the ability to manage. The better the management of the school principal, it will undoubtedly impact teacher motivation to complete and carry out their work so that it will improve teacher performance. However, it does not rule out that other factors influence a teacher's performance in carrying out his duties. This is undeniable through several studies, which show that many factors contribute to high or low teacher performance.

This study has limitations in that it only performs analysis using the principal managerial ability and performance motivation variables to determine the effect on teacher performance. Some suggestions that can be followed up by other researchers based on the results of this study are that there are efforts from related agencies to be able to improve the competence of school principals through organizing workshops and training and optimizing supervision of the performance of school principals. In addition, it is necessary to identify more factors that influence teacher performance apart from the variables of performance motivation and managerial ability of leaders. This is because many factors influence and contribute to teacher performance in carrying out their duties and obligations. Other researchers can follow up by holding training activities and further research by adding or replacing broader variables.

\section{CONCLUSION}

Based on the results of data analysis regarding the effect of principal managerial skills and motivation on performance of teachers in SDN, Bonang District, Demak Regency, it can be identified that the principal managerial skills have a significant effect on teacher performance in SDN, Bonang District, Demak Regency. Work motivation has a significant effect on the performance of teachers in SDN areas of Bonang District, Demak. As well as principal managerial skills and work motivation together have a significant effect on teacher performance in the SDN area of Bonang District, Demak Regency. Through the results of this study, it can be identified that teacher performance is influenced by several factors, namely the performance motivation factor itself and the factor of the principal's ability to manage the running of the system in an educational institution. Practically the principal must have good institutional management competence so as to realize the vision and mission of the institution. The findings in this study can become a basis for educational supervision to find solutions in an effort to improve the quality of education and can provide awareness for leaders in educational institutions, namely schools that their role in managing an institution will affect the performance of employees, especially teachers.

\section{REFERENCES}

Ahmadiansah, R. (2018). Pengaruh Motivasi Kerja dan Kepuasan Kerja Terhadap Kinerja Guru SMK Muhammadiyah Salatiga. Journal of Materials Processing Technology, 1(1), 1-8. https://doi.org/10.18326/inject.v1i2.223-236.

Alfathan, I. H., \& Saleh, A. (2018). Gaya Kepemimpinan dan Intensitas Komunikasi GPPT dengan Efektivitas Kelompok di Sekolah Peternakan Rakyat. Jurnal Sains Komunikasi Dan Pengembangan Masyarakat [JSKPM], 2(3), 289-300. https://doi.org/10.29244/jskpm.2.3.289-300.

Almutairi, T. S., \& Shraid, N. S. (2021). Teacher evaluation by different internal evaluators: Head of departments, teachers themselves, peers and students. International Journal of Evaluation and Research in Education, 10(2), 588-596. https://doi.org/10.11591/ijere.v10i2.20838.

Amri, S., Murniati, N. A. N., \& Miyono, N. (2021). Pengaruh Keterampilan Manajerial Kepala Sekolah Dan Budaya Sekolah Terhadap Efektivitas Sekolah. Jurnal Manajemen Pendidikan (JMP), 9(3), 269-277. https://doi.org/10.26877/jmp.v9i3.8118.

Arikunto, S. (2010). Prosedur Penelitian Ilmiah. In Rineka cipta, Jakarta.

Ariyani, D. (2021). Principal's Innovation and Entrepreneurial Leadership to Establish a Positive Learning Environment. European Journal of Educational Research, 10(1), 63-74. https://doi.org/10.12973/eujer.10.1.63.

Ariyanti, Y. (2020). Keterampilan Manajerial Kepala Sekolah dalam Meningkatkan Kinerja Guru. AKSES: Jurnal Ekonomi Dan Bisnis, 14(1), 26-35. https://doi.org/10.31942/akses.v14i1.3265.

Aryantini, Agung, \& Dantes. (2018). Kontribusi Implementasi Manajemen Sekolah Berbasis Nilai-Nilai Kearifan Lokal Tri Hita Karana, Kepemimpinan Pelayan Kepala Sekolah, Budaya Sekolah dan Kepuasan Kerja Terhadap Kinerja Guru di SMP Negeri Kecamatan Sukasada Kabupaten Buleleng. 
Jurnal Administrasi Pendidikan Indonesia, 9(2), 99-110. https://doi.org/10.23887/japi.v9i2.2757.

Danim, S. (2012). Motivasi Kepemimpinan \& Efektivitas Kelompok. Jakarta: Rineka Cipta.

Dery, K. (2021). The Ideological Perspective of School Principals’ Perceptions-Educational Leaders Defining their Roles. European Journal of Educational Management, 1(4), 13-23. https://doi.org/10.12973/eujem.4.1.13.

Dhiu, K. D. (2017). Learning Motivation And Perception Of The Teachers' Pedagogic Competence And Learning Achievement In Social Science Of Junior High School Students. Journal of Education Technology, 1(1), 6-12. https://doi.org/10.23887/jet.v1i1.10078.

Fanselow, M. S. (2018). Emotion, motivation and function. Current Opinion in Behavioral Sciences, 19, 105109. https://doi.org/10.1016/j.cobeha.2017.12.013.

Hartanti, A. S., \& Yuniarsih, T. (2018). Pengaruh Kompetensi Profesional Guru Dan Motivasi Kerja Terhadap Kinerja Guru Di Sekolah Menengah Kejuruan. Jurnal Pendidikan Manajemen Perkantoran, 3(1), 167. https://doi.org/10.17509/jpm.v3i1.9452.

Lisnawati, R. (2018). Fungsi Manajemen Kepala Sekolah, Motivasi, dan Kinerja Guru. Jurnal Pendidikan (Teori Dan Praktik), 2(2), 143-149. https://doi.org/10.26740/jp.v2n2.p143-149.

Lumban Gaol, N. T., \& Siburian, P. (2018). Peran Kepala Sekolah Dalam Meningkatkan Kinerja Guru. Kelola: Jurnal Manajemen Pendidikan, 5(1), 66-73. https://doi.org/10.24246/j.jk.2018.v5.i1.p66-73.

Mangkunegara, A. P. (2014). Evaluasi Kinerja. Bandung: Refika Aditama.

Maris, I. S., Komariah, A., \& Bakar, A. (2016). Kepemimpinan Transformasional Kepala Sekolah, Kinerja Guru Dan Mutu Sekolah. Jurnal Administrasi Pendidikan, 23(2), 173-188. https://doi.org/10.17509/jap.v23i2.5645.

Ningrat, S. P., Agung, A. A. G., \& Yudana, I. M. (2020). Kontribusi Etos Kerja, Motivasi Kerja, Disiplin Kerja dan Supervisi Akademik Terhadap Kinerja Guru Sd Gugus VII Kecamatan Mengwi. Jurnal Administrasi Pendidikan Indonesia, 3(1), 42-52. https://doi.org/10.23887/japi.v11i1.3169.

Pratiwi, W. A., Prasetyo, I., \& Shabrina, M. N. (2021). Faktor-Faktor yang Berpengaruh terhadap Kinerja Guru Taman Kanak-Kanak. Jurnal Obsesi: Jurnal Pendidikan Anak Usia Dini, 5(2), 1741-1753. https://doi.org/10.31004/obsesi.v5i2.970.

Purwoko, S. (2018). Pengaruh kepemimpinan kepala sekolah, komitmen guru, disiplin kerja guru, dan budaya sekolah terhadap kinerja guru SMK. Jurnal Akuntabilitas Manajemen Pendidikan, 6(2), 149-162. https://doi.org/10.21831/amp.v6i2.8467.

Putri, A. D. K., \& Imaniyati, N. (2017). Pengembangan Profesi Guru Dalam Meningkatkan Kinerja Guru. Jurnal Pendidikan Manajemen Perkantoran, 2(2), 93-101. https://doi.org/10.17509/jpm.v2i2.8109.

Ramadoni, Kusmintardjo, \& Arifin. (2016). Kepemimpinan Kepala Sekolah Dalam Upaya Peningkatan Kinerja Guru (Studi Multi Kasus Di Paud Islam Sabilillah Dan SDN Tanjungsari 1 Kabupaten Sidoarjo. Jurnal Pendidikan, 1(8). http://dx.doi.org/10.17977/jp.v1i8.6620.

Sari, H. P. (2019). Pengaruh Kompetensi, Motivasi Kerja Dan Insentif Terhadap Kinerja Guru SMA. Perspektif Ilmu Pendidikan, 33(1). https://doi.org/https://doi.org/10.21009/PIP.331.8.

Satriyono, G., \& Vitasmoro, Pa. (2018). Pengaruh Kecerdasan Emosional Terhadap Kinerja Guru Di SMP Negeri 4 Kediri. Jurnal Ekonomi Universitas Kediri, 3(1), 31-45. https://doi.org/10.30737/ekonika.v3i1.104.

Suardana, I. P., Yudana, M., \& Agung, A. A. G. (2018). Kontribusi Gaya Kepemimpinan, Kompetensi Profesional dan Kompetensi Manajerial Kepala Sekolah Terhadap Motivasi Kerja (Studi Tentang Persepsi Guru SMAN 1 Mengwi). Jurnal Administrasi Pendidikan Indonesia, 9(1), 55-66. https://doi.org/10.23887/japi.v9i1.2736.

Sudiarditha, I. K. R., Waspodo, A. W., \& Triani, N. A. (2017). Pengaruh Lingkungan Kerja dan Motivasi Kerja Terhadap Kepuasan Kerja Karyawan Pada Direktorat Umum Lembaga Pelayanan Publik Televisi Republik Indonesia. Jurnal Manajemen, 20(2), 278. https://doi.org/10.24912/jm.v20i2.48.

Sudirman, A., Candra, V., Dharma, E., \& Lie, D. (2021). Determinants of Teacher Performance : Exploring the Role of Satisfaction and Motivation as Mediation. Jurnal Pendidikan Dan Pengajaran, 54(1), 68-79.

Sumantri, M. S., \& Whardani, P. A. (2017). Relationship between Motivation to Achieve and Professional Competence in the Performance of Elementary School Teachers. International Education Studies, 10(7), 118. https://doi.org/10.5539/ies.v10n7p118.

Ulum, M. B., Sarwoko, E., \& Yuniarinto, A. (2020). Kepemimpinan Kepala Sekolah Dan Kinerja Guru: Peran Mediasi Motivasi Kerja. Jurnal Administrasi Dan Manajemen Pendidikan, 3(4), $299-307$. https://doi.org/10.17977/um027v3i42020p299.

Usman, \& Husaini. (2015). Model Kepemimpinan Instruksional Kepala Sekolah. Cakrawala Pendidikan, 34(3). https://doi.org/10.21831/cp.v3i3.7338.

Wahyudi. (2012). Kepemimpinan Kepala Sekolah dalam Organisasi Pembelajar (Learning Organization). Bandung: Alfabeta. 
Werang, B. R. (2011). Hubungan Keterampilan Manajerial Kepala Sekolah , Iklim Sekolah , dan Moral Kerja Guru dengan Kinerja Guru SMA Negeri di Kota Merauke. JAM: Journal Aplikasi Manajemen, 10(3), 595-605. Retrieved from https://jurnaljam.ub.ac.id/index.php/jam/article/view/442.

Widodo, H. (2017). Keterampilan Manajerial Kepala Sekolah. NATURALISTIC: Jurnal Kajian Penelitian Pendidikan Dan Pembelajaran, 2(1), 85-93. https://doi.org/10.35568/naturalistic.v2i1.105.

Yayuk, S., \& Sugiyono, S. (2019). Pengaruh kepemimpinan kepala sekolah dan biaya pendidikan terhadap kualitas proses belajar mengajar dan dampaknya dengan kompetensi lulusan SMK di kabupaten Gunungkidul. Jurnal Akuntabilitas Manajemen Pendidikan, 7(1), 84-96. https://doi.org/10.21831/amp.v7i1.23758.

Yusuf, M. (2012). Kinerja Kepala Sekolah dan Guru dalam Mengimplementasikan Pendidikan Inklusif. Jurnal Pendidikan Dan Kebudayaan, 18(4). https://doi.org/10.24832/jpnk.v18i4.96. 